\title{
STUDIES ON THE MODE OF ACTION OF ORAL CONTRACEPTIVES: EFFECT OF CHLORMADINONE ON PITUITARY FSH AND LH CONTENTS OF THE FEMALE RAT
}

\author{
ANANT P. LABHSETWAR* \\ Department of Anatomy, Washington University School of Medicine, \\ St. Louis, Missouri, U.S.A.
}

(Received 2nd October 1967, revised 21st November 1967)

\begin{abstract}
Summary. Chlormadinone, a very potent synthetic progestagen, was administered subcutaneously for 10 days $(400 \mu \mathrm{g} / \mathrm{day})$ to intact, unilaterally and bilaterally spayed rats, either adult or immature, and pituitary levels of FSH (HCG augmentation method of Steelman \& Pohley, 1953) and LH (OAAD method of Parlow, 1958) were determined. The chlormadinone treatment induced a significant atrophy of the ovaries as well as ovarian interstitial tissue and a total blockade of ovarian compensatory hypertrophy in the unilaterally spayed rats. The pituitary concentration $(\mu \mathrm{g} / \mathrm{mg})$ and the total content $(\mu \mathrm{g} / \mathrm{gland})$ of both LH and FSH were significantly increased by chlormadinone treatment of the intact and unilaterally spayed rats despite a significant atrophy of the pituitary gland due to treatment. In the bilaterally spayed adult and immature rats, chlormadinone did not alter the ovariectomy-induced rise in LH and FSH stores of the pituitary gland.

These results suggest that chlormadinone, when administered for 10 days in the dosages employed, induces storage of FSH and LH in the pituitary gland primarily by impairing the release of these hormones, without exerting any detectable inhibitory effects on their synthesis.
\end{abstract}

\section{INTRODUCTION}

Despite their widespread use in fertility control and gynaecological disorders, the exact mode of action of synthetic progestagens remains obscure. Although it is likely that the total effectiveness of these agents probably results from their action at multiple sites in the body (such as the ovary, uterine tubes, uterus, cervix, pituitary and hypothalamus), their primary action is believed to be exerted at the pituitary-hypothalamic level, inhibiting the output of luteinizing hormone (LH) and consequently ovulation (Vorys, Ullery \& Stevens, 1965; Flowers, Vorys, Stevens, Miller \& Jensen, 1966).

* Present address: Imperial Chemical Industries Ltd, Pharmaceutical Division, Biological Research Department, Alderley Park, Macclesfield, Cheshire.

$D^{*}$ 
Previously it has been reported that prolonged administration of a progesterone derivative, Provera, results in depletion of pituitary LH stores (Labhsetwar, 1966b), while the administration of a 19-nor steroid derivative, norethynodrel, for a period of 10 or less days was found to result in a significant increase in the pituitary LH content of the female (Labhsetwar, 1967b) as well as the male rat (Brown, Wells \& Youngson, 1965).

In the present study one of the most potent derivatives of progesterone, chlormadinone (6-chloro- $\Delta^{6}-17 \alpha$-acetoxyprogesterone), was employed. It is estimated to be 3500 times more active than norethisterone, both in the Clauberg assay and anti-ovulatory test in the rabbit (Rudel \& Kincl, 1966). As little as $0.5 \mathrm{mg}$ of the compound taken orally without oestrogen has been reported to exert a contraceptive effect in women (Martinez-Manautou, Cortez, Giner, Aznar, Casasola \& Rudel, 1966). It exhibits a very mild anti-gonadotrophic activity in parabiotic rats (Brennan \& Kray, 1963) and has been found virtually free from virilizing (Kraay \& Brennan, 1963) and androgenic properties (see Rudel \& Kincl, 1966). Additionally it is a true progestagen in the sense that it can maintain pregnancy in spayed rats (Brennan \& Kraay, 1963). It is of considerable interest to study the mode of action of such a compound in influencing the secretion of gonadotrophins (FSH and $\mathrm{LH}$ ).

\section{MATERIALS AND METHODS}

Female rats of the Holtzman strain were caged in a temperature- and light- (14 $\mathrm{hr}$ of artificial illumination and $10 \mathrm{hr}$ of darkness) controlled room and allowed free access to Purina chow and water.

Five experiments, as outlined in Table 1, were performed, employing five different types of rats. Experiments 1 and 2 were repeated at a later date (1B and $2 \mathrm{~B}$, Table 1). In any given experiment the control and the treated animals were of the same age, were run simultaneously and also killed on the same day, except in Exp. 1B (see Table 1).

Chlormadinone was prepared in corn or sesame oil and injected once a day subcutaneously for 10 days. The daily dose was $400 \mu \mathrm{g} / \mathrm{rat}$ (approximately $1.50 \mathrm{mg} / \mathrm{kg}$ in adult and $4 \mathrm{mg} / \mathrm{kg}$ in immature rats).

One day after the last injection the rats were killed with ether. The anterior pituitary glands were removed, blotted to remove excess blood, and immediately weighed. The glands within each experimental group were pooled and kept frozen $\left(-20^{\circ} \mathrm{C}\right)$ for subsequent bio-assays. The ovaries (when present), adrenal glands and uteri were then also weighed. All autopsies were performed between 08.00 and 11.30 hours.

\section{Output of gonadotrophins}

This was evaluated in Exps. 2A, 2B and 3 by studying the ovarian compensatory hypertrophy in unilaterally spayed rats as described elsewhere (Labhsetwar, 1967c).

\section{Ovarian sensitivity}

To test the ovarian sensitivity, immature rats (26 days old) were primed with PMSG and HCG as described under LH assay. Beginning $48 \mathrm{hr}$ after HCG injection, 
when all ovulations have presumably occurred, the animals received daily subcutaneous injections of $400 \mu \mathrm{g}$ (or about $4 \mathrm{mg} / \mathrm{kg}$ ) of chlormadinone in oil for 8 days. A day after the last injection, the left ovary was removed as control and $1 \mu \mathrm{g}$ of $\mathrm{LH}$ (NIH-LH-S-11) was injected into a tail vein. The remaining ovary was removed $4 \mathrm{hr} \pm 10 \mathrm{~min}$ later and the ascorbic acid (AA) content was determined. The percentage depletion of $\mathrm{AA}$ was calculated by comparing the 'treated' ovary with the control removed from the same animal.

\section{Bio-assay for $L H$}

The LH level was determined by a slight modification (Labhsetwar, 1967c) of the OAAD method of Parlow (1958), employing one ovary and a 4-hr interval. With the exception of experiment $1 \mathrm{~A}$, where a two plus one assay design was

TABLE 1

DETAILS OF VARIOUS EXPERIMENTS PERFORMED

\begin{tabular}{|c|c|c|c|c|}
\hline $\begin{array}{c}\text { Experiment } \\
\text { no. }\end{array}$ & $\begin{array}{l}\text { Operative* } \\
\text { procedure }\end{array}$ & $\begin{array}{l}\text { Age at } \\
\text { commencement } \\
\text { of treatment }\end{array}$ & $\begin{array}{l}\text { Daily } \\
\text { dose } \\
\text { (ug/rat) }\end{array}$ & Remarks \\
\hline $1 \mathrm{~A}$ & None & 76 & 400 & $\begin{array}{l}\text { Control animals killed without regard } \\
\text { to stage of the oestrous cycle }\end{array}$ \\
\hline IB & None & 92 & 400 & $\begin{array}{l}\text { Control animals killed when they } \\
\text { showed first di-oestrous vaginal smear } \\
\text { on or after the day of autopsy of the } \\
\text { treated animals }\end{array}$ \\
\hline $2 \mathrm{~A}$ & $\begin{array}{l}\text { Unilateral } \\
\text { ovariectomy }\end{array}$ & 75 & 400 & $\begin{array}{l}\text { Only ovarian compensatory hyper- } \\
\text { trophy studied }\end{array}$ \\
\hline $2 B$ & $\begin{array}{l}\text { Unilateral } \\
\text { ovariectomy }\end{array}$ & 85 & 400 & \\
\hline 3 & $\begin{array}{l}\text { Unilateral } \\
\text { ovariectomy }\end{array}$ & 36 & 400 & \\
\hline 4 & $\begin{array}{l}\text { Bilateral } \\
\text { ovariectomy }\end{array}$ & 95 & 400 & \\
\hline 5 & $\begin{array}{l}\text { Bilateral } \\
\text { ovariectomy }\end{array}$ & 36 & 400 & $\begin{array}{l}\text { Rats became bilaterally spayed as a } \\
\text { result of their previous use in oAAD. } \\
\text { Treatment started approximately } 18 \\
\text { hr post-ovariectomy }\end{array}$ \\
\hline
\end{tabular}

* All operations were performed under ether anaesthesia; treatment was started on the day of surgery.

used, a symmetrical four-point design with two doses of standard LH $(0 \cdot 8 \mu \mathrm{g}$ and $4 \mu \mathrm{g}$ of NIH-LH-s-11) and two doses of pituitary tissue $(0.4 \mathrm{mg}$ and $2 \mathrm{mg})$ was employed. In the bilaterally spayed rats the doses of the pituitary glands were reduced by half. Initially one ovary was used and the second ovary was used $48 \mathrm{hr}$ later. Four or five assay rats/dose were employed. The assay statistics (relative potency, confidence limits, index of precision, etc.) were calculated according to the method described by Gaddum (1953) for parallel line assays. The mean index of precision $(\lambda)$ for ten determinations was $0.251 \pm 0.05$ (s.E.).

Bio-assay for FSH

A slight modification (Labhsetwar, 1967c) of the method of Steelman \& 


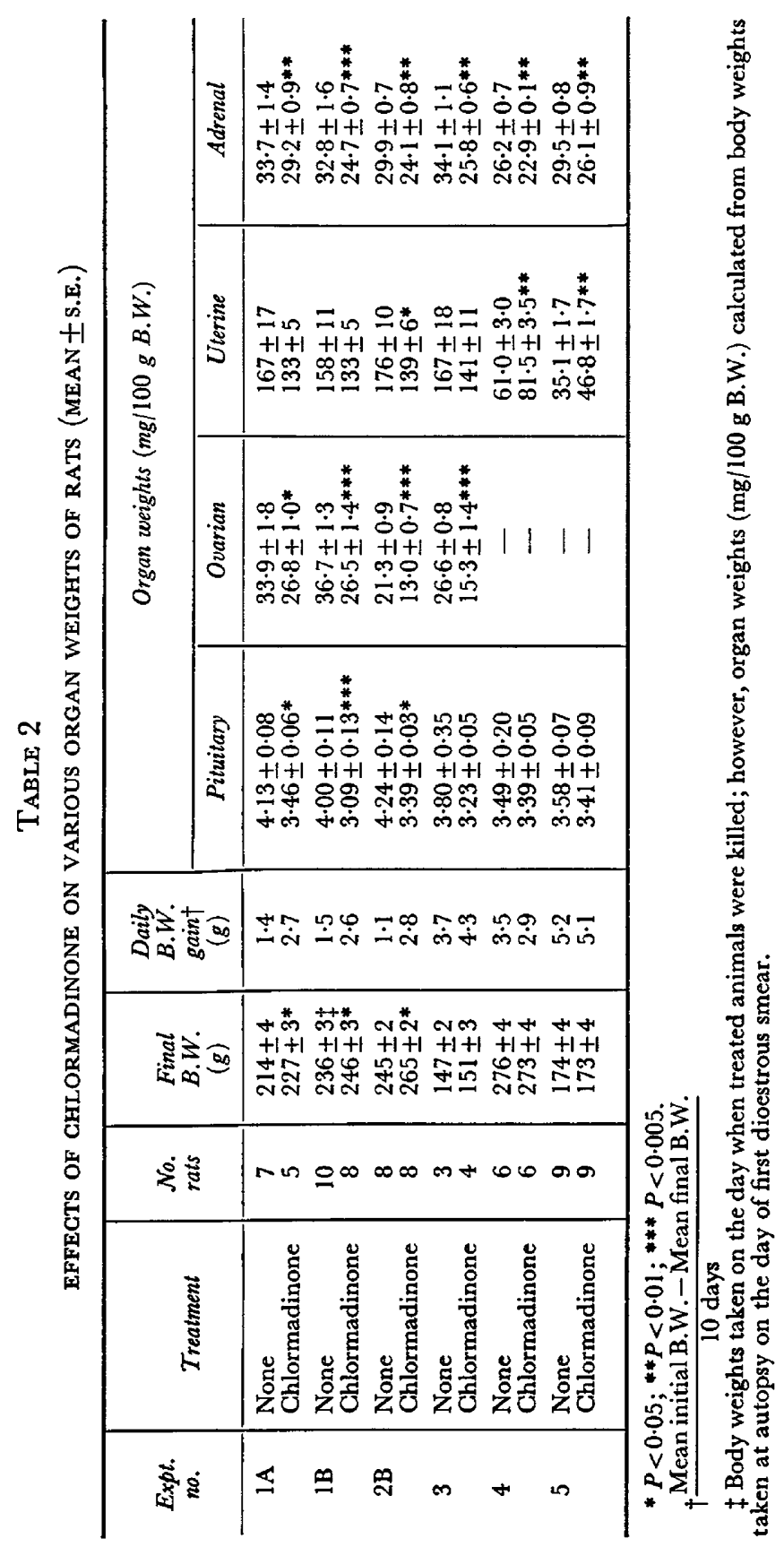


Pohley (1953) was used. The assays were conducted on two occasions. Each assay included two doses of reference standard (NIH-FsH-s-3) and one dose of unknown from each treatment group, several unknowns being tested on each occasion. The augmenting dose of HCG was $40 \mathrm{i} . u$. /rat, and three or four assay rats/dose were used. The index of precision calculated from pooled sum of squares and combined slope was found to be $0 \cdot 123$, which is well within acceptable range.

\section{Body weight}

\section{RESULTS}

Administration of chlormadinone to rats with one or both ovaries resulted in a significant increase in body weight $(P<0 \cdot 05$, Table 2$)$. The mean daily body weight gain in three groups of adult treated rats (two intact and one unilaterally spayed) was significantly higher than a similar mean for three corresponding control groups $(2.70 \pm 0.03 \mathrm{~g}$ versus $1.33 \pm 0.18 \mathrm{~g}, P<0.01)$. Bilateral ovariectomy itself significantly increased the body-weight gain; chlormadinone failed to augment this weight gain, either in adult or immature rats (Table 2).

\section{Organ weights}

The chlormadinone administration resulted in a significant atrophy of the pituitary glands, ovaries and adrenals in the intact and unilaterally spayed rats, both on a relative $(\mathrm{mg} / 100 \mathrm{~g}$ body wt, Table 2$)$ and an absolute $(\mathrm{mg} / \mathrm{rat}$, Tables 3 and 4) body weight basis. In the adult rats, bilateral ovariectomy itself reduced the pituitary and adrenal weights significantly when compared with the intact controls (Table 2); chlormadinone in these rats further reduced the adrenal but not the pituitary weights $(P<0.01$, Table 2$)$.

In the intact and unilaterally spayed rats treated with chlormadinone, the relative uterine weights were consistently and sometimes significantly $(P<0.05)$ lower than those of the respective controls. In contrast, in the bilaterally spayed adult as well as immature rats treated with progestagen, uterine weights were significantly higher than those of the respective controls $(P<0 \cdot 05$, Table 2), confirming the previous report (Harper, 1964). At autopsy none of the treated rats with one or both ovaries revealed ballooned uteri, while in the control groups (except in Exp. 3) some of the animals showed this condition.

\section{Ovarian histology}

Paraffin sections $(7 \mu)$ were stained either with haematoxylin-eosin or a tetrachrome method, which selectively stains collagen. The corpora lutea in the treated animals, although fewer in number, appeared healthy and contained fewer connective tissue elements than the controls. Vesicular follicles of varying sizes, up to but not including pre-ovulatory size, were present in the ovaries of the treated animals, but most of them appeared atretic. The interstitial tissue in the ovaries of the treated animals also appeared atrophic.

\section{Ovarian compensatory hypertrophy}

Progestagen treatment resulted in inhibition of ovarian compensatory hypertrophy in all experiments (Table 3), and prevented the compensatory increase 
in the number of corpora lutea usually seen in the unilaterally spayed rats (Table 3).

\section{Ovarian sensitivity}

Chlormadinone treatment did not significantly affect the ovarian weights $(225 \pm 18 \mathrm{mg}$ in control, versus $200 \pm 13 \mathrm{mg}$ in treated, $P>0.05)$ or initial AA concentration (48.8 in control, versus $51.1 \mu \mathrm{g} / 100 \mathrm{mg}$ of ovary in the treated). Furthermore, exogenous LH caused the same degree of AA depletion in the treated as in the control animals $(17 \cdot 3 \pm 2 \cdot 3$, versus $20 \cdot 7 \pm 5 \cdot 6 \%, P>0.05)$.

\section{TABLE 3}

INFLUENCE OF GHLORMADINONE ON OVARIAN COMPENSATORY HYPERTROPHY AND LUTEAL GOUNT IN UNILATERALLY SPAYED RATS (MEAN \pm S.E.)

\begin{tabular}{|c|c|c|c|c|c|c|}
\hline $\begin{array}{c}\text { Experiment } \\
\text { no. }\end{array}$ & Treatment & $\begin{array}{l}\text { No. } \\
\text { rats }\end{array}$ & $\begin{array}{c}\text { Left } \\
o v . w t . \\
\langle m g\rangle^{e}\end{array}$ & $\begin{array}{l}\text { Right } \\
\text { ov. wt.a } \\
(m g)^{e}\end{array}$ & $\begin{array}{c}\text { Ovarian } \\
\text { hypertrophy } \\
(\%)\end{array}$ & $\begin{array}{l}\text { No. } \\
C L \text { in } \\
\text { rt ov. }\end{array}$ \\
\hline $2 \mathrm{~A}$ & $\begin{array}{l}\text { None } \\
\text { Chlormadinone }\end{array}$ & $\begin{array}{l}4 \\
5\end{array}$ & $\begin{array}{l}38 \cdot 0 \pm 2 \cdot 7 \\
35 \cdot 0 \pm 2 \cdot 5\end{array}$ & $\begin{array}{l}56 \cdot 5 \pm 1 \cdot 2^{\text {c** }} \\
33 \cdot 0 \pm 1 \cdot 0\end{array}$ & 49 & $\begin{array}{l}9 \cdot 7 \pm 0 \cdot 5 \\
5 \cdot 0 \pm 0 \cdot 7^{0 * *}\end{array}$ \\
\hline 2B & $\begin{array}{l}\text { None } \\
\text { Chlormadinone }\end{array}$ & $\begin{array}{l}8 \\
8\end{array}$ & $\begin{array}{l}38 \cdot 2 \pm 1 \cdot 5 \\
40 \cdot 7 \pm 3 \cdot 3\end{array}$ & $\begin{array}{l}52 \cdot 2 \pm 2 \cdot 3^{c * *} \\
34 \cdot 5 \pm 1 \cdot 9\end{array}$ & 37 & $\begin{aligned} 11 \cdot 9 & \pm 0 \cdot 4 \\
6 \cdot 2 & \pm 2 \cdot 5^{b *}\end{aligned}$ \\
\hline $3^{d}$ & $\begin{array}{l}\text { None } \\
\text { Chlormadinone }\end{array}$ & $\begin{array}{l}3 \\
4\end{array}$ & $\begin{array}{l}17 \cdot 0 \pm 2 \cdot 7 \\
15 \cdot 4 \pm 1 \cdot 2\end{array}$ & $\begin{array}{l}39 \cdot 0 \pm 1 \cdot 1^{c * * * *} \\
23 \cdot 0 \pm 2 \cdot 2^{c *}\end{array}$ & $\begin{array}{r}129 \\
49\end{array}$ & $\begin{array}{l}10 \cdot 3 \pm 1 \cdot 2 \\
3 \cdot 5 \pm 1 \cdot 2^{0 * *}\end{array}$ \\
\hline
\end{tabular}

* $P<0.05 ; * * P<0.01 ; * * * P<0.005$.

a Weighed 10 days after removal of left ovary.

b Significantly different from the respective controls.

c Significantly different from left ovarian weight.

d Vaginae of all animals except one were closed at the time of first injection on 36 th day of life.

e mg/rat.

\section{Pituitary LH and FSH}

In the control animals unilateral ovariectomy did not significantly modify the pituitary levels of either LH or FSH (Table 4), confirming the previous reports (Edgren, Parlow, Peterson \& Jones, 1965; Labhsetwar, 1967c). In contrast, the removal of both ovaries resulted in a several-fold increase in the pituitary stores of both gonadotrophins (Table 4).

Administration of chlormadinone to intact and unilaterally spayed rats resulted in marked increases $(>100 \%)$ in the concentration $(\mu \mathrm{g} / \mathrm{mg})$ and the total content ( $\mu \mathrm{g} /$ pituitary) of both LH and FsH (Table 3). The gonadotrophin content $(\mu \mathrm{g} / \mathrm{gland})$ increased, despite a significant atrophy of the pituitary gland both on a relative (Table 2) and an absolute basis (Table 4) due to treatment.

In the bilaterally spayed adult and immature rats, progestagen treatment did not alter the ovariectomy-induced rise in the pituitary stores of either LH or FSH (Table 4).

\section{FSH $L H$ ratio}

The ratio of FsH concentration $(\mu \mathrm{g} / \mathrm{mg})$ to that of $\mathrm{LH}$ was always in favour of FSH in both the control and the treated animals. The removal of one or both ovaries or administration of chlormadinone did not materially affect the ratio (Table 4). 


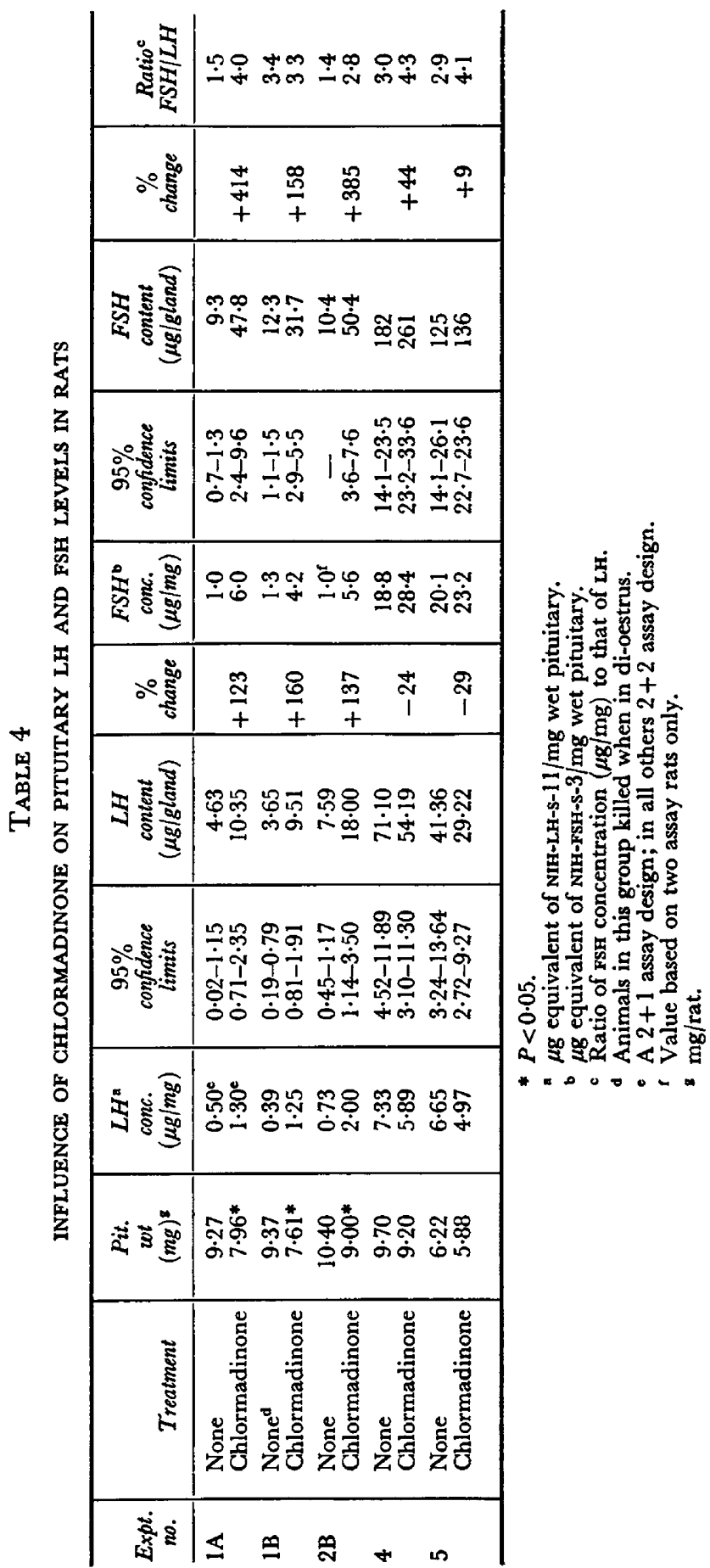




\section{DISGUSSION}

The data suggest that chlormadinone administration results in increased pituitary stores of FSH and LH. A significant atrophy of the ovaries in the intact treated rats (Table 2), together with an inhibition of ovarian compensatory hypertrophy (Table 3), a lack of compensatory increase in the number of corpora lutea in the unilaterally spayed rats (Table 3 ) and the atrophy of the interstitial tissue of the ovary indicate either a decline in the output of FSH and LH, or a decrease in the ovarian sensitivity to these hormones. However, ovaries of immature pseudopregnant rats treated with this progestagen were as sensitive to the ovarian-ascorbic-acid-depleting activity of exogenous $\mathrm{LH}$ as those of the controls. Furthermore, ovaries in rats (Harper, 1964) and rabbits (Rudel \& Kincl, 1966) treated with this compound remain capable of responding to gonadotrophins. These observations, taken together, preclude a significant peripheral action of the agent. Therefore our observations can be most readily explained by assuming a decline in the discharge of both FSH and LH from the pituitary gland of the treated rats. The decreased output of FSH and LH associated with their increased pituitary stores suggests that chlormadinone primarily impaired the release of these hormones, without significantly interfering with their synthesis in the pituitary gland. This is further corroborated by the failure of this compound to reduce the ovariectomy-induced rise in the pituitary levels of FsH and LH (Table 4).

Harper (1965) postulated, from the augmented uterine response to placental gonadotrophins of immature rats fed chlormadinone, that this progestagen causes storage of gonadotrophins in the pituitary gland. The present study involving adult rats provides experimental evidence in support of this hypothesis, and further demonstrates that the storage involves both FSH and LH.

The storage of gonadotrophins in the pituitary may result from the action of the compound at the pituitary and/or hypothalamic level, or it may be secondary to its ability to induce pseudopregnancy. The latter condition is associated with increases in the pituitary stores of LH and FSH (Van Rees \& de Groot, 1965; Labhsetwar, 1967a; Schwartz \& Rothchild, 1964), while progesterone (Everett, 1964) as well as synthetic progestagen-norethynodrel (Labhsetwar, 1966a) have been found capable of inducing pseudopregnancy in the rat.

It seems that inhibition of $\mathrm{LH}$ release by chlormadinone is partial, involving only the ovulatory surge of the hormone. The presence of vesicular follicles of varying sizes in the ovaries of the treated animals indicates that gonadotrophins (particularly FSH) adequate to support follicular growth were being secreted in the presence of chlormadinone. These follicles probably secrete oestrogens, since significant uterine atrophy did not always result after administration of chlormadinone to animals with one or both ovaries. Alternatively, the uterotrophic action of the agent may have overcome the oestrogen deficiency resulting from reduction in LH output. The uterotrophic property of this agent was evident in the absence of both ovaries (Table 2).

Two important properties of this compound observed in this study, are its ability to (i) increase body weight, and (ii) cause an atrophy of the pituitary gland, both on an absolute and a relative basis, in intact and unilaterally 
spayed rats. Since both of these effects were absent in the bilaterally spayed rats, they appear to be mediated through the ovary and most probably result from neutralization of effects of endogenous oestrogens by chlormadinone. The anti-oestrogenic property of this compound is well documented (Kraay \& Brennan, 1963). In contrast, the adrenolytic effect of chlormadinone appears to be independent of the ovaries (Table 2).

\section{ACKNOWLEDGMENTS}

The author wishes to thank Dr A. C. Enders for his interest and support throughout the course of the work and for advice on histological procedures employed in this study.

Acknowledgment is also made to Dr Beall of Ayerst Laboratories for supplies of Equinex and A.P.L., to Dr Dorfman of Syntex Laboratories and Dr McGuire of Eli Lilly Company for chlormadinone, and to the Endocrine Study Section of NIH for supplying reference standards (FSH and LH). This study was supported by grant GB-2476 from the United States National Science Foundation, and grant T1 HD 21 from the National Institutes of Child Health and Human Development.

\section{REFERENCES}

BREnNAN, D. M. \& KraAy, R. J. (1963) Chlormadinone acetate, a new highly active gestationsupporting agent. Acta endocr., Copenh. 44, 367.

Brown, P. S., Welis, M. \& Youngson, A. (1965) Effect of norethynodrel on pituitary gonadotrophic potency in intact male rats. Nature, Lond. 205, 88.

Edgren, R. A., Parlow, A. F., Peterson, D. L. \& Jones, R. C. (1965) On the mechanism of ovarian hypertrophy following hemicastration in rats. Endocrinology, 76, 97.

EveretT, J. W. (1964) Central neural control of reproductive functions of the adenohypophysis. Physiol. Rev. 44, 373.

Flowers, C. E., Jr, Vorys, N., Stevens, V., Miller, A. T. \& Jensen, L. (1966) The effects of suppression of menstruation with ethynodiol diacetate upon pituitary, ovary and endometrium. Am. 7. Obstet. Gynec. 96, 784.

Gaddum, J. H. (1953) Simplified mathematics for bioassays. 7. Pharm. Pharmac. 6, 345.

HARPER, M. J. K. (1964) The effect of chlormadinone on the response of the ovaries and uterus of the immature rat to gonadotrophic stimulation. F. Endocr. 30, 235.

HARPER, M. J. K. (1965) Augmentation by chlormadinone of the uterine weight response to human chorionic gonadotrophin in intact immature rats. 7. Endocr. 33, 447.

KRAAY, R. J. \& BRENNAN, C. M. (1963) Evaluation of chlormadinone acetate and other progestogens for foetal masculinization in rats. Acta endocr., Copenh. 43, 412.

LABHSETWAR, A. P. (1966a) Induction of pseudopregnancy in the rat with norethynodrel. Proc. Endocr. Soc., 48 th Meeting, p. 126.

LABHSETWAR, A. P. (1966b) Mechanism of action of medroxyprogesterone (17 $\alpha$ acetoxy-6- $\alpha$-methyl progesterone) in the rat. F. Reprod. Fert. 12, 445.

LABHSETWAR, A. P. (1967a) Hysterectomy and hypophysial levels of FSH and LH. F. Reprod. Fert. 13, 169.

LABHSETWAR, A. P. (1967b) Effects of norethynodrel and mestranol on pituitary $\mathrm{LH}$ in the female rat. 7. Reprod. Fert. 14, 379.

LABHSETWAR, A. P. (1967c) Differential effects of reserpine on pituitary luteinizing hormone and follicle-stimulating hormone levels in the female rat. Endocrinology, 81, 357.

Martinez-Manautou, J., Cortez, V., Giner, J., Aznar, R., Casasola, J. \& Rudel, H. (1966) Low doses of progestogen as an approach to fertility control. Fert. Steril. 17, 49.

Parlow, A. F. (1958) A rapid bioassay method for LH and factors stimulating LH secretion. Fedn Proc. Fedn Am. Socs exp. Biol. 17, 402.

Ruder, H. W. \& KincL, F. A. (1966) The biology of antifertility steroids. Acta endocr., Copenh., Suppl. 105,1 .

SCHWARTZ, N. \& RothChILD, I. (1964) Changes in pituitary LH concentration during pseudopregnancy in the rat. Proc. Soc. exp. Biol. Med. 116, 107. 
Steelman, S. L. \& Pohley, F. (1953) Assay of the follicle stimulating hormone based on the augmentation with human chorionic gonadotrophin. Endocrinology, 53, 604.

VAN REes, G. P. \& DE GROOT, C. A. (1965) Secretion of FSH and LH in the pseudopregnant rat. Acta endocr., Copenh. 49, 370.

Vorys, N., Ullery, J. G. \& Stevens, V. (1965) The effects of sex steroids on gonadotropins. Am. J. Obstet. Gynec. 93, 641 . 